\title{
Humic substances in peats (Sumatra, Indonesia)
}

\author{
É. Garnier-Sillam, S. Hariyento and Y. Bourezgui \\ Laboratoire de Biologie des Sols et des Eaux, Université Paris XII, 94000 Créteil, France
}

\begin{abstract}
The peats of the Jambi region of Sumatra have been cultivated for many years by the villagers, after minor draining works. Their humification process was investigated using a chronosequence: T0 (control soil), 3 years, 6 years and 9 years of cultivation. The extraction of the humic substances at different $\mathrm{pH}$ reveals that the $\mathrm{pH} 12$ extractant gives rise to false conclusions concerning the polymerized nature of the humic acids extracted. Elemental and molecular analyses confirmed their aliphatic nature, and hence their neoformed character.
\end{abstract}

plots cultivated for three years (T3), six years (T6) and nine years (T9). The entire chronosequence is located in a geographically limited space in order to minimize the heterogeneities of the landscape (identical vegetation and geological substrate). The sites selected are characterized by identical types of development, crop practices and cultivated species (pineapple, vegetables, coffee, maize and fruit trees: rambutan, coconut, jackfruit). The role of drainage on the physical and physicochemical state of this substrate has been investigated [5]. The humification process involved in the constitution of these "soils" has been considered, and we deal here with methodological and interpretative problems with which we were faced.

\section{Material and methods}

\section{Introduction}

The rising demographic pressure and the concomitant acceleration in development activities are generating increasing land demand in the countries of the inter-tropical regions. Since the most fertile lands are already being exploited, these countries must turn to lands and landscapes that development officials normally turned down as too difficult to work or infertile [1].

The peat bogs in Indonesia cover an estimated 24 millions hectares. They occupy vast areas along the eastern coast of Sumatra, in western and southern Kalimantan, and in southern Irian Jaya $[2,3]$. The natural vegetation of the bogs is a dense forest, where the trees can be 25 to $30 \mathrm{~m}$ high. These peats consist of practically pure, unevolved organic matter, resulting from the decomposition of the plant material from the ancient and present forest. The study site was located in the neighbourhood of the village of Pematang Lumut in Sumatra's Jambi province. The peat bogs are cultivated by the villagers after minor drainage works, connected to the main hydrological network established by the State [4]. In the field, this translates into a complete transformation of the environment. This transition from an essentially water environment of interlacing branches and tree trunks to an environment which, while still organic, is structured like a true "soil", as referred to in pedology, is one of the major issues of the dynamics of these landscapes.

We defined a chronosequence starting with a forest peat (time T0) identified as the reference soil, continuing through a succession of plots whose "age" corresponds to the length of time they have been cultivated. We thus selected three

\section{Peat characteristics}

The peat bogs about $3 \mathrm{~m}$ thick overlie a quartz mineral substrate. The influence of the substrate is negligible. Analysis of the total elements of the peats showed that they contain about 5\% (T0) and 8\% (T9) ash of exclusively biological origin. The acidity of the soil and drainage waters is high, with $\mathrm{pH}$ ranging from 3 to 3.5 . The differences between the $\mathrm{pH}_{\mathrm{H}_{2} \mathrm{O}}$ and the $\mathrm{pH}_{\mathrm{KCl}}$ reveal that the potential acidity decreases with the age of cultivation [5].

Morphological analyses showed that the cultivation time influenced the structure of the peats. Hence the T0 peats of the fibroid type progressively change to the saprobic type in nine years of cultivation [6]. The weighted mean diameter of the aggregates, which is $2.12 \mathrm{~mm}$ at T0, gradually grows from year to year to reach $3.21 \mathrm{~mm}$ in nine years of cultivation [5].

\section{Extraction of humic compounds}

Given the difficulties (choice of extractant, neoformed products) encountered by the researchers working on European peat bogs [7-9] and after a number of laboratory tests, we decided to use the following protocols and to compare the results obtained with $2 \mathrm{~g}$ of test sample per $100 \mathrm{~mL}$ of solution $(n \times 5)$ :

extraction with sodium pyrophosphate at $\mathrm{pH} 10$ for $16 \mathrm{~h}$ with stirring,

extraction with $0.1 \mathrm{~N}$ sodium hydroxide $(\mathrm{pH} \mathrm{12)} \mathrm{for} 16 \mathrm{~h}$ with stirring. 
The procedure is unconventional and the results have only comparative value.

The fulvic acids and humic acids are separated on an aliquot of total humic matter by precipitation of the humic acids in the presence of $2 \mathrm{~N}$ sulphuric acid at $\mathrm{pH} 1$ (for $4 \mathrm{~h}$ ). After centrifugation, the humic acids present in the deposit are washed with $0.1 \mathrm{~N}$ sulphuric acid solution and dissolved in a small volume of $0.1 \mathrm{~N}$ sodium hydroxide, while the fulvic acids remain in the supernatant. Organic carbon and organic nitrogen are determined in each fraction using an Ionics 1555 TOC meter and the Büchi Kjeldahl.

\section{Humic acid purification and analysis}

After extraction, the humic acids present in the peats are redissolved in sodium hydroxide $(0.1 \mathrm{~N})$ or in sodium pyrophosphate, and again undergo three successive precipitations at $\mathrm{pH} 1$. After resolubilization and $\mathrm{pH}$ adjustment to 7 , the extracts are then dialysed using dialysis membranes of Spectra-Por 6 type cellulose ester with a cutoff threshold corresponding to a molecular weight of 1000 D. Dialysis continues for several days in the presence of regularly renewed distilled water. The sample is then lyophilized. The humic substances were characterized by spectrophotometric methods using the ratio E4/E6 of the optical densities at 465 and $665 \mathrm{~nm}$. This ratio is independent of the concentration, and varies with the condensation of the humic substances $[10,11]$. Elemental analysis of the humic acids was performed on a Carlo Erba CHNO device.

\section{Results and discussion}

\section{Total carbon and nitrogen contents}

The peats analyzed were essentially organic: $92 \%$ at $\mathrm{T} 9$ and $95 \%$ at $\mathrm{T} 0$. The $\mathrm{C} / \mathrm{N}$ ratios are given in figure 1 . The surface strata display a $\mathrm{C} / \mathrm{N}$ varying from 30 at $\mathrm{T} 0$ to 24 at $\mathrm{T} 9$, and the $\mathrm{C} / \mathrm{N}$ ratios of the deeper strata $(40$ to $50 \mathrm{~cm}$ ) vary
C/N

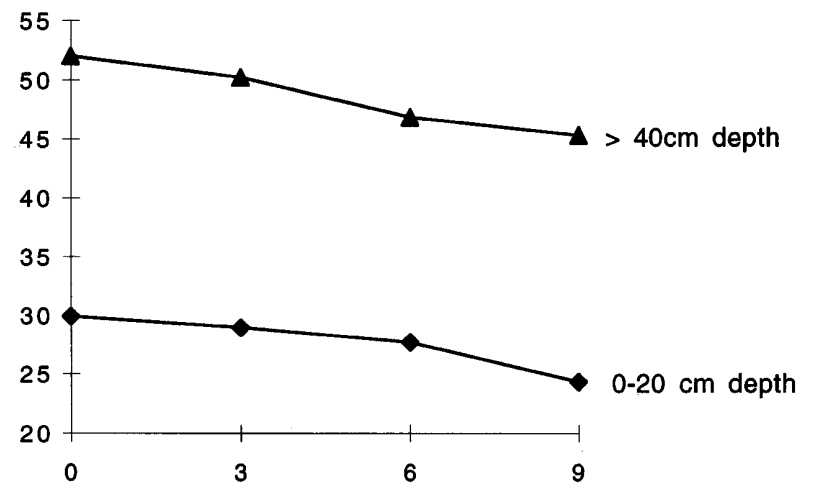

Time of cultivation (years)

Figure 1. $\mathrm{C} / \mathrm{N}$ of peat organic matter versus depth and cultivation time.

from 52 at T0 to 45 at T9. For the element carbon, for both strata, a decrease of about $2 \%$ of its content was observed as a function of the cultivation age of the peat. The nitrogen content decreased rapidly with depth. These contents were correlated with the ash contents.

\section{Analysis of the soluble fraction}

Humic substances extracted by sodium pyrophosphate

Table I gives the alkali-soluble extraction rates (carbon and nitrogen) and the carbon and nitrogen FA/HA ratios in the surface horizons of the four peats of different ages. On the whole, no pronounced differences appeared in the distribution of humic substances in the peats analyzed. The carbon and nitrogen (FA/HA) ratios were consistently lower than 1 . These values were essentially due to a very low fulvic acid concentration in all the peats. A slight increase in humic acid content was observed with age of cultivation. These trends

Table I. Extraction rate of alkaline-soluble (FA+HA) substances and distribution of fulvic acids (FA) and humic acids (HA) in the surface horizons of the peats (mean + standard deviation) as a function of $\mathrm{pH}$.

\begin{tabular}{|c|c|c|c|c|c|c|c|c|c|}
\hline & & \multicolumn{2}{|c|}{ Alkaline-soluble $(A F+A H)$} & \multicolumn{2}{|c|}{ Fulvic acids } & \multicolumn{2}{|c|}{ Humic acids } & \multirow[t]{2}{*}{$(F A / H A) C$} & \multirow[t]{2}{*}{$(F A / H A) N$} \\
\hline & & $\% C$ & $\% \circ N$ & $\% C$ & $\% \circ N$ & $\% C$ & $\% \circ N$ & & \\
\hline \multirow[t]{2}{*}{$\mathrm{TO}$} & $\mathrm{pH} 10$ & $20.4(0.5)$ & $6.1(0.2)$ & $4.0(0.2)$ & $1.2(0.1)$ & 16.4 & 4.9 & 0.27 & 0.24 \\
\hline & $\mathrm{pH} 12$ & $25.4(1.1)$ & $10.3(0.5)$ & $8.8(0.6)$ & $4.0(0.2)$ & 16.6 & 6.3 & 0.52 & 0.63 \\
\hline \multirow[t]{2}{*}{$\mathrm{T} 3$ years } & $\mathrm{pH} 10$ & $22.2(0.9)$ & $7.6(0.4)$ & $4.6(0.3)$ & $1.2(0.1)$ & 17.6 & 6.4 & 0.26 & 0.19 \\
\hline & $\mathrm{pH} 12$ & $28.6(0.8)$ & $10.9(0.6)$ & $9.7(0.4)$ & $3.1(0.2)$ & 18.9 & 7.8 & 0.51 & 0.4 \\
\hline \multirow[t]{2}{*}{ T 6 years } & $\mathrm{pH} 10$ & $23.8(0.6)$ & $8.1(0.3)$ & $4.8(0.3)$ & $1.3(0.1)$ & 19 & 6.8 & 0.25 & 0.18 \\
\hline & $\mathrm{pH} 12$ & $34.6(1.2)$ & $17.2(0.7)$ & $11.1(0.5)$ & $5.1(0.3)$ & 23.5 & 12.1 & 0.47 & 0.42 \\
\hline \multirow[t]{2}{*}{ T 9 years } & $\mathrm{pH} 10$ & $24.7(0.4)$ & $7.9(0.2)$ & $5.0(0.2)$ & $1.2(0.1)$ & 19.7 & 6.7 & 0.24 & 0.17 \\
\hline & $\mathrm{pH} 12$ & $39.5(1.0)$ & $18.5(0.8)$ & $12.8(0.6)$ & $5.4(0.4)$ & 26.7 & 13.1 & 0.44 & 0.41 \\
\hline
\end{tabular}


give rise to a decreasing tendency of the carbon and nitrogen (FA/HA) ratios with age of cultivation $(0.27$ at $\mathrm{T} 0$ to 0.24 at $\mathrm{T} 9$ for the $\mathrm{C}(\mathrm{FA} / \mathrm{HA})$ ratios, and 0.24 at $\mathrm{T} 0$ to 0.17 at $\mathrm{T} 9$ for the $\mathrm{N}$ (FA/HA) ratios. The change in these ratios could confirm a more pronounced process of humification in the older peat. The extraction rate (FA + HA/TOC ratio) increases by about $5 \%$ from $\mathrm{T} 0$ to $\mathrm{T} 9$ in the surface horizons.

\section{Humic substances extracted by sodium hydroxide}

Like the above results, the distribution in relative values of the different humic substances extracted by $\mathrm{NaOH}$ shows that the upper horizons of the peats display an increase in the alkali-soluble carbon extraction rate, related to the ageing of the peat (extraction rate $25.4 \%$ at $\mathrm{T} 0$, and $39.5 \%$ at T9). This increase is specifically due to the humic acid content. In fact, although the fulvic acid extraction rates rose substantially in comparison with extraction by pyrophosphate, their values vary less between the different surface peats $(\mathrm{FA}(\mathrm{T} 0)=8.8 \mathrm{~g} / 100 \mathrm{~g}$, FA $(\mathrm{T} 9)=12.8 \mathrm{~g} / 100 \mathrm{~g})$, than those of the humic acids (HA (T0) $=16.4 \mathrm{~g} / 100 \mathrm{~g}$, HA $($ T9) $=26.7 \mathrm{~g} / 100 \mathrm{~g}$ ).

\section{Comparison of alkaline extraction methods}

Regardless of the peat concerned (T0 or T9), the extraction of humic substances by $\mathrm{pH} 12$ sodium hydroxide causes an increase in the extraction rates from about 30 to $40 \%$ carbon, and 35 to $57 \%$ nitrogen, in comparison with $\mathrm{pH} 10$ sodium pyrophosphate. This increase in the extraction rates is greater in $\mathrm{T} 9$ peat in comparison with $\mathrm{T} 0$ peat, regardless of the element concerned (carbon or nitrogen).

These functional modifications could be explained by auto-oxidation in alkaline media, due to the elevation of the $\mathrm{pH}$ [13]. For fulvic acids (FA), the increase in the fulvic acid extraction yield at $\mathrm{pH} 12$, compared with extraction at $\mathrm{pH} 10$, could be due to a small degree to the hydrolysis of $\mathrm{HA}$ at high $\mathrm{pH}$, and primarily to the extraction of small indissociable molecules of a fulvic nature. Alkaline auto-oxidation processes with an increase in the $\mathrm{C}=\mathrm{O}$ groups cannot be discounted [13].

Some authors $[14,15]$ have demonstrated that the extraction kinetics of phenolic compounds is a practically exponential function of the $\mathrm{pH}$ for values ranging from 10 to 14 . The extractability of other relatively indissociable or lowacid fractions increases similarly with $\mathrm{pH}$. Schnitzer and Khan [16] reported the production of phenolic $\mathrm{OH}$ by the alkaline degradation of methoxyl groups and the possible opening of paraketotetrahydropyrone type cycles, a structure found in humic compounds and their precursors when the $\mathrm{pH}$ is raised.

However, since the differences in contents found after the use of the two reagents were high, we attempted to determine whether, at the molecular level, the products extracted displayed differences between each other as a function of the age of cultivation of the peats.

\section{UV-visible spectrophotometric analysis of humic acids}

The E4/E6 ratio, which is independent of concentration, decreases with increasing molecular size and hence polycondensation increases. The results (Fig. 2) show that, with respect to total humic acids, the ratio E4/E6 decreases from T0 to T9 years, demonstrating the presence of more polymerized molecules as a function of peat cultivation age, but the results of the E4/E6 ratios obtained at $\mathrm{pH} \mathrm{12,} \mathrm{compared}$ with those obtained at $\mathrm{pH} 10$, show that, with this extractant, we had access to molecules that were very slightly condensed and were much more aliphatic than aromatic.

\section{Elemental composition of humic acids}

The results of the elemental analysis of the humic acids (Tab. II) confirm this character, revealing a higher content of hydrogen atoms in comparison with carbon atoms in the molecules extracted at $\mathrm{pH} 12$ (shown here by the $\mathrm{H} / \mathrm{C}$ ratio). Thus the humic acids extracted at $\mathrm{pH} 12$ exhibit a more aliphatic character than those extracted at $\mathrm{pH} 10$. This result can be explained by a number of assumptions. Considering the higher fulvic acid content extracted with sodium hydroxide, and the results obtained on humic acids (E4/E6 ratio and $\mathrm{H} / \mathrm{C}$ ratio), it is plausible to assume that the increase in the aliphatic character of the humic acids, in correlation with the higher $\mathrm{pH}$, results either from the extraction of large lipid, carbohydrate or protein molecules, or from some aliphatization of molecules resulting from the oxidative opening of the aromatic rings [12].

Chen and Schnitzer [16] showed that FA and HA are only organized into linear networks at neutral and alkaline $\mathrm{pH}$, whereas, in acidic medium, they assume a condensed and more spheroid form. Hence, in the case of the samples investigated, the families of high molecular weight compounds extracted with sodium hydroxide could consist of molecules exhibiting a high percentage of aliphatic chains developed,

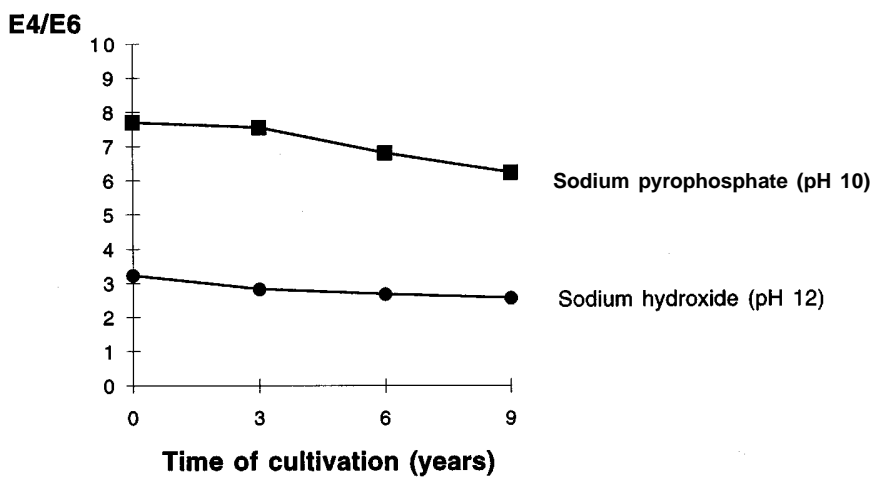

Figure 2. E4/E6 UV ratio of humic acids in peats as a function of time. 
Table II. Atomic ratios of humic acids in peats.

\begin{tabular}{ccccc}
\hline & & $H / C$ & $O / C$ & $N / C$ \\
\hline \multirow{2}{*}{ TO } & $\mathrm{pH} \mathrm{10}$ & 1.2 & 0.43 & 0.02 \\
& $\mathrm{pH} \mathrm{12}$ & 1.34 & 0.51 & 0.03 \\
$\mathrm{~T} 9$ & $\mathrm{pH} \mathrm{10}$ & 1.0 & 0.41 & 0.04 \\
& $\mathrm{pH} \mathrm{12}$ & 1.11 & 0.48 & 0.06 \\
\hline
\end{tabular}

or even connected, under the influence of the extractant $\mathrm{pH}$ and generating a high molecular size.

\section{Conclusions}

We can accordingly make two types of conclusion for this part of the study.

Methodological: it is undesirable, for acidic peats, to recommend the use of strong alkaline extractants for the study of the alkali-soluble elements, since their use leads to false conclusions concerning the interpretation of the actual humification process. Indeed, this extractant creates neoformed products of large molecular size.

Agronomic: the extraction rates of humic substances in all the peats are low and vary slightly in nine years of cultivation.

The FA/HA ratios, much lower than 1 , are due to the low fulvic carbon and nitrogen contents. This result is certainly explained by the exit of a portion of humic molecules in the drainage water. The humification degree, as understood in pedology, is expressed only slightly. Indeed, the maturation of humic compounds is inhibited by several factors such as acidity, temporary hydromorphia, low bacterial biomass and absence of mineral.

The evolution of the plant matter of the acidic peats cultivated after drainage acquire a "soil" status primarily due to physical and morphological changes. Chemical changes play only a minor role in this transformation from fibroid to the saprobic type. Two antagonistic mechanisms are at play. Drainage on the one hand which accelerates the mineralization and hence the disappearance of the peat, but which allows the substrate to develop a physical structure. And, on the other hand, the strong hydromorphia and acidity of the medium which slow biochemical mineralization as well as maturation.

Peats are an extremely fragile medium which must be managed with extreme care. In particular, the drainage canals must remain small in order to prevent their accelerated disappearance in a period of drought.

\section{References}

1. Anderson, J. A. R. In: Mires: Swamp Bog Fen and Moor. 4B Regional Studies, Gore, A. J. P. Ed., Elsevier, Amsterdam, 1983; pp 181-199.

2. Sudjadi, M. In: Ecology and Management of Problem soils in Asia. Juang, T. C. Eds., Food and fertilizers Technology Center for the Asian and Pacific Region, Taiwan, 1984; pp 58-73.

3. Sieffermann, R. G. Ann. Géogr. 1988, 97(544), 642-666.

4. Beaudou, A. G.; Le Martret, H. In: Miruram, Analyse intégrée des systèmes villageois indonésiens. CD Rom, ORSTOMDepartement Transmigrasi dan PPH, 1996.

5. Hariyento, S. Transformations des tourbes de Jambi (SumatraIndonésie) après mise en culture traditionnelle, Thèse de l’Université Paris XII, 1997.

6. Dinel, H.; Levesque M. Can. J. Soil Sci. 1976, 56, 119-120.

7. Boelter, D. H. Soil Sci. Soc. Amer. Proc. 1969, 33, 606-609.

8. Jambu, P. Contribution à l'étude de l'humification dans les sols hydromorphes calciques. Les sols du Marais Poitevin. Thèse Doct. État, Université de Poitiers, 1971.

9. Menut, G. Recherches écologiques sur l'évolution de la matière organique des sols tourbeux. Thèse de spécialité, U.E.R. Nancy I. S.T.M.C.M., 1974.

10. Schnitzer, M.; Khan, S. U. Soil organic matter, Elsevier Amsterdam, 1979, p 308.

11. Chamayou, H.; Legros, J. P. In: les bases physiques chimiques et minéralogiques de la science du sol. Press. Univ. France, 1989; pp 174-231.

12. Barriuso, E. Caractérisation des fractions organo-minérales et des constituants humiques d'un sol de pelouse subalpine, Thèse de $3^{\text {ème }}$ cycle Université, Nancy I, 1985.

13. Swift, R. S.; Posner, A. M. J. Soil Sci. 1972, 23, 381-393.

14. Whitehead, D. C.; Dibb, H.; Hartley, R. D. Soil Biol. Biochem. 1981, 13, 343-348.

15. Schnitzer, M.; Khan, S. U. Humic substances in the environment, Dekker Inc., M. Eds., New York, 1972; p 372.

16. Chen, Y.; Schnitzer, M. Soil Sci. Soc. Am. J. 1976, 40, $682-686$ 